\title{
Ancillary techniques on the evaluation of canine cutaneous mast cell tumors from Brazil
}

\author{
Técnicas auxiliares avaliação de mastocitomas cutâneos caninos do Brasil
}

\author{
Mariana Martins Flores ${ }^{I}$ Renata Dalcol Mazaro ${ }^{I I}$ \\ Ingeborg Maria Langohr III Alma Roy ${ }^{\text {II }}$ Keith Strother ${ }^{\text {III }}$ Rafael Almeida Fighera ${ }^{\text {IV }}$
}

\section{ABSTRACT}

The use of histologic classification by a 2-tier grading system only, immunohistochemistry (IHC) for KIT and Ki-67 and polymerase chain reaction (PCR) for internal tandem duplications (ITD) on exon 11 has improved the prognostication of canine cutaneous mast cell tumors (CCMTs) particularly in the United States. However, these techniques are not commonly used in most Brazilian laboratories. Likewise, no studies, to date, have investigated the occurrence of ITD in CCMTs from the country. Thus, this study tested the 2-tier grading system, the immunohistochemistry for KIT and Ki67 and the PCR for exon 11 in a group of Brazilian CCMTs with the goal of investigating the applicability of these tests in a Brazilian laboratory. Of the 39 CCMTs, 69.2\% (27/39) were identified as lowgrade and 30.8\% (12/39) as high-grade by a 2-tier grading system. All tumors had a KIT expression pattern II, and 30.6\% (11/36) had a high growth fraction (Ki-67). PCR amplification was successful in four of the 11 tumors examined. Two of these (50\%) were positive for ITD. This study highlights the importance of using auxiliary techniques in the CCMT evaluation, identifies limitations and confirms the applicability of these methods on a routine diagnostic basis in Brazil. Our results will help to improve the prognostication of CCMTs in Brazilian diagnostic laboratories, encouraging the use of supplementary methods.

Key words: immunohistochemistry, Ki-67, mutations, PCR, mast cell tumor.

\section{RESUMO}

O uso de classificação histológica por um novo sistema de graduação que utiliza apenas duas categorias, imuno-histoquímica
(IHQ) para KIT e Ki-67 e reação de polimerase em cadeia (PCR) para mutações (duplicações internas) no éxon 11 tem melhorado a avaliação do prognóstico de mastocitomas cutâneos caninos (MCCs), particularmente nos Estados Unidos. No entanto, essas técnicas são ainda pouco utilizadas em laboratórios brasileiros e, até então, nenhum estudo investigou a prevalência de duplicações internas (DIs) em MCCs do país. Este estudo testou o novo sistema de graduação histológica de duas categorias, a imuno-histoquímica para KIT e Ki-67 e o PCR para exon 11 em um grupo de MCCs brasileiros, com o objetivo de investigar a aplicabilidade desses métodos em um laboratório brasileiro. De 39 MCCs, 69,2\% foram identificados como sendo de baixo grau e 30,8\% como de alto grau. Todos tiveram um padrão II de expressão de KIT, e 30,6\% (11/36) tiveram uma alta contagem para Ki-67. A amplificação foi bem-sucedida em quatro dos 11 tumores examinados. Dois destes (50\%) foram positivos para DIs. Este estudo ressaltou a importância do uso de técnicas auxiliares na avaliação de MCCs, identificou limitações e confirmou a aplicabilidade desses métodos em uma rotina de diagnósticos no Brasil. Esses resultados irão auxiliar na melhor avaliação prognóstica dos MCCs em laboratórios brasileiros, encorajando o uso de métodos suplementares neste processo.

Palavras-chave: imuno-histoquímica, Ki-67, mutações, PCR, mastocitoma.

\section{INTRODUCTION}

Cutaneous mast cell tumor is a common skin cancer of dogs, known by its highly variable biological

\footnotetext{
IPrograma de Pós-graduação em Medicina Veterinária, Área de Concentração em Patologia e Patologia Clínica Veterinária, Centro de Ciências Rurais (CCR), Universidade Federal de Santa Maria (UFSM), 97105-900, Santa Maria, RS, Brasil. E-mail: marianamflores@yahoo.com.br. Corresponding author.

IIDepartamento de Medicina Veterinária, Centro de Ciências Rurais (CCR), Universidade Federal de Santa Maria (UFSM), Santa Maria, RS, Brasil.

IIILouisiana Animal Disease Diagnostic Laboratory (LADDL), Department of Pathobiological Sciences (PBS), Louisiana State University (LSU), Baton Rouge, LA, United States of America.

${ }^{\text {IV }}$ Departamento de Patologia, Centro de Ciências da Saúde (CCS), Universidade Federal de Santa Maria (UFSM), Santa Maria, RS, Brasil. Received 02.23.16 Approved 04.20.16 Returned by the author 07.01.16 CR-2016-0255.R1
} 
behavior (GOLDSCHMIDT \& HENDRICK, 2002; GROSS et al., 2005). Identifying biologically aggressive canine cutaneous mast cell tumors (CCMTs) is quite challenging. Histopathology is one of the most consistent tools used for this purpose, among which the most commonly used grading system is the one proposed by PATNAIK et al. (1984). Despite of the fact of being the most known grading method, the Patnaik System (PS) has been strongly criticized for its subjective criteria (VASCELLARI et al., 2012; SABATTINI et al., 2015) and the poor prognostic value of its intermediate category (grade II) (VASCELLARI et al., 2012). Recently, a 2-tier grading system has been proposed (KIUPEL et al., 2011) which divides the CCMTs solely in low-grade and high-grade tumors. Despite of the noticeable improvement in the histological grading provided by the Kiupel system (KS), to date, no grading system is able to predict the prognosis of most CCMTs.

A set of mutations termed "internal tandem duplications" (ITD) affecting the exon 11 of the $c$-kit gene has been associated with the development of some mast cell tumors in dogs (LONDON et al., 1999; DOWNING et al., 2002; ZEMKE et al., 2002). The affected tumors seem to be more aggressive (DOWNING et al., 2002; ZEMKE et al., 2002), but also respond more effectively to specific therapies (PRYER et al., 2003). These aspects have stimulated the inclusion of a PCR for exon 11 as a new prognostic test for CCMTs. Use of immunohistochemistry for the tyrosine kinase receptor (KIT) and for Ki-67 as other prognostic indicators for MCCT has also been established (KIUPEL et al., 2004; WEBSTER et al., 2007; VASCELLARI et al., 2012). In recent years, the pattern of KIT expression by neoplastic mast cells (KIUPEL et al., 2004) as well as the Ki-67 count (SCASE et al., 2006; WEBSTER et al., 2007, VASCELLARI et al., 2012) showed correlated prognostic indicators such as survival time and neoplastic recurrence.

In the United States, the PCR for exon 11 and the IHC for KIT and Ki-67 are used on a routine diagnosic basis to increase the chances of identifying biologically aggressive tumors. Nevertheless, supplementary techniques for MCCTs evaluation are still little used in most Brazilian laboratories. This study tested the new 2-tier grading system (KIUPEL et al., 2011), the immunohistochemistry for KIT and Ki-67 and the PCR for exon 11 in a group of CCMTs diagnosed in a Brazilian laboratory, with the main goal of investigating the applicability of these different techniques in a routine diagnostic basis in Brazil. Thus, it encourages the use of auxiliary methods in the prognostication of CCMTs.

\section{MATERIALS AND METHODS}

The biopsy archive (2010-2015) of the Laboratório de Patologia Veterinária (LPV) of the Universidade Federal de Santa Maria (UFSM) was searched for canine cutaneous mast cell tumors. Only cases that have been diagnosed as cutaneous mast cell tumors and classified as grade II according to PS (PATNAIK et al., 1984) by the same pathologist (R.F.) were included. Paraffin blocks and hematoxylin and eosin slides from these tumors were retrieved and sent to the Louisiana Animal Disease Diagnostic Laboratory (LADDL), Louisiana State University (LSU), Baton Rouge, Louisiana, United States. At the LADDL, a second pathologist (I.L.) graded the CCMTs following the novel 2-tier grading system proposed by KIUPEL et al. (2011). Thereafter, all cases were submitted to immunohistochemistry (IHC) for KIT and Ki-67, and, based on the IHC results, a subset of cases was selected for PCR for exon 11 of the $c$-kit gene. The amplicons with mutations were sent for sequencing.

The IHC protocol for KIT and Ki-67 was similar to those previous publications (KIUPEL et al., 2004; WEBSTER et al. 2007). Slides were incubated with primary antibodies against KIT (pAb, 1:200, Dako, A4502) ${ }^{\mathrm{I}}$ and Ki-67 (MIB$1 \mathrm{mAb}, 1: 50$, Dako, M7240) ${ }^{\mathrm{I}}$ for 30 minutes at $37^{\circ} \mathrm{C}$. A streptavidin-immunoperoxidase staining procedure was used for immunolabeling. The 3,3'-diaminobenzidine substrate (Dako) ${ }^{\mathrm{I}}$ was used as chromogen. Sections were counter and stained with Mayer's hematoxylin (Anatech) ${ }^{\mathrm{II}}$.

According to KIUPEL et al. (2004), the KIT IHC slides were divided into: pattern I, characterized by membrane staining; pattern II, characterized by focal or stippled cytoplasmic staining; or pattern III, characterized by diffuse cytoplasmic staining. The Ki-67 IHC slides were interpreted according to WEBSTER et al. (2007). After identifying areas with the highest number of labeled neoplastic cells, the number of positive cells present in a $10 \times 10 \mathrm{~mm}$ grid area was manually counted using a $1 \mathrm{~cm}^{2}(10 \times 10)$ grid reticle at $400 \mathrm{X}$ magnification. The number of positive cells per grid area was counted over 5 high-power fields (hpf) and averaged. This number was termed "growth fraction" (WEBSTER et al., 2007). CCMTs were divided into two groups: tumors with a low growth fraction $(<23)$ and tumors with a high growth fraction ( $\geq 23$ ). Based on previous criteria (KIUPEL et al., 2004, WEBSTER et al.. 2007), only the cases most likely positive for ITD were submitted to PCR, 
namely those with KIT expression patterns II or III and with a high growth fraction.

Extraction was performed using a commercially available kit (Qiagen QIAamp DNA FFPE Tissue $K^{\circledR} t^{\circledR}$, Quiagen, 56404) $)^{\mathrm{III}}$. Four $5 \mu \mathrm{m}$ sections of each block were cut and placed in $2 \mathrm{ml}$ tubes. Paraffin was removed by treatment with xylene and ethanol. Samples were dried and $180 \mu$ l of ATL buffer and $20 \mu 1$ of proteinase K were added. Samples were incubated in $56^{\circ} \mathrm{C}$ for an hour and subsequently in $90^{\circ} \mathrm{C}$ for another hour. The tubes were placed inside the QIAcube of genomic DNA from FFPE tissue sections" was selected. After extraction, samples were stored in a $-20^{\circ} \mathrm{C}$ refrigerator. A negative extraction control (NEC) was included in the extraction procedure.

The PCR protocol for exon 11 and intron 11 was performed using the following primers: PE1/ PE2 (PE1: CCCATGTATGAAGTACAGTGGAAG; PE2: GTTCCCTAATCATTGTTACACG) (JONES et al., 2004). A non-diluted sample and a 1:10 sample were tested. The PCR reaction was performed by using PE1/PE2 for initial denaturation at $98^{\circ} \mathrm{C}$ for 20 seconds, followed by 40 cycles of $98^{\circ} \mathrm{C}$ for 20 seconds, $65.7^{\circ} \mathrm{C}$ for 30 seconds, $72^{\circ} \mathrm{C}$ for 30 seconds and then a $72^{\circ} \mathrm{C}$ for 10 minutes step. The PCR product was analyzed by using agarose gel electrophoresis (agarose gel in Tris-acetate-EDTA buffer, 4\%). Gel amplifications from the positive cases for ITD were sent to Genelab (LSU) for sequencing. GeneLab performs sequence analysis using the Applied Biosystems $^{\circledR}$ (ABI) 3130 Genetic Analyzer (ABI standard protocols). The sequences were analyzed using the DNASTAR Lasergene ${ }^{\circledR} 12$ software. A positive CCMT (PCR+) and a negative CCMT (ITD) for mutations were included as controls. A negative PCR control was also used (PCR-).

This study used as a statistical analysis, the simple regression model to determine the relationship between the histologic grade and growth rate. Correlation between these variables was assessed through the Pearson correlation coefficient. Analyses were done using Statgraphics Centurion ${ }^{\circledR} \mathrm{XV}$ version 15.1.

\section{RESULTS}

A total of 39 CCMTs met the inclusion criteria in this study. According to the 2-tier grading system (KIUPEL et al., 2011), 69.2\% (27/39) of these were identified as low-grade and $30.8 \%(12 / 39)$ as high-grade tumors. The most frequent malignancy criteria seen in the high-grade tumors was the presence of 7 or more mitotic figures in $10 \mathrm{hpf}(8 / 12$ [66.7\%]) (Figure 1a). In the four high-grade tumors with a low mitotic index, karyomegaly $(n=3)$ (Figure $1 b)$, bizarre nuclei $(n=1)$ and multinucleated cells $(n=1)$ were seen.

The IHC for KIT and Ki-67 failed in one (KIT) and three (Ki-67) cases, due to loss of the tissue during processing $(\mathrm{n}=2)$ or failure of immune labeling $(n=2)$. All the other KIT IHC cases $(38 / 38)$ were considered as having an expression pattern II (Figure 1c). From the Ki-67 IHC slides, 69.4\% $(25 / 36)$ had a low growth fraction (Figure 1d). Of these, $80 \%(20 / 25)$ were low-grade tumors. About a third of the cases $(11 / 36$ [30.6\%]) had a high growth fraction (Figure 1d), 63.6\% (7/11) of which were high-grade tumors. With the statistical analysis, a moderate correlation $(\mathrm{r}=0.43)$ between the histologic grade and the growth fraction was established. Eleven cases were selected for PCR.

The PCR was considered well succeeded when at least one band was seen in the agarose gel electrophoresis. Cases with two bands were considered positive for ITD: the lower band corresponded to the normal c-kit gene while the upper band corresponded to the $c$-kit gene containing the internal tandem duplication (LONDON et al., 1999; ZEMKE et al., 2002). Exon 11 from the $c$-kit gene was successfully amplified in four samples $(4 / 11[36.4 \%])$. Of these, two $(2 / 4[50 \%])$ were negative for mutations and two $(2 / 4[50 \%])$ were positive (Figure 2). Of the two positive cases, one was a low-grade and the other was a high-grade tumor.

\section{DISCUSSION}

This study investigated the histological grade, growth fraction and KIT expression pattern of 39 CCMTs previously classified as intermediate grade, allowing the identification of a group of potentially aggressive tumors. Additionally, the PCR for exon 11 identified two positive tumors for internal tandem duplications (ITD). These mutations have been extensively investigated in the United States (LONDON et al., 1999; DOWNING et al., 2002; ZEMKE et al., 2002; WEBSTER et al., 2007), but they have not been explored in Brazil. It was also investigated the applicability of IHQ and PCR for MCCTs in Brazil and recognized important limitations on the use of these techniques in this country.

The grading system proposed by KIUPEL et al. (2011) (KS) is currently considered as one of the best histological grading systems for CCMT (VASCELLARI et al., 2012; TAKEUCHI et al., 2013; MAULDIN \& PETERS-KENNEDY, 


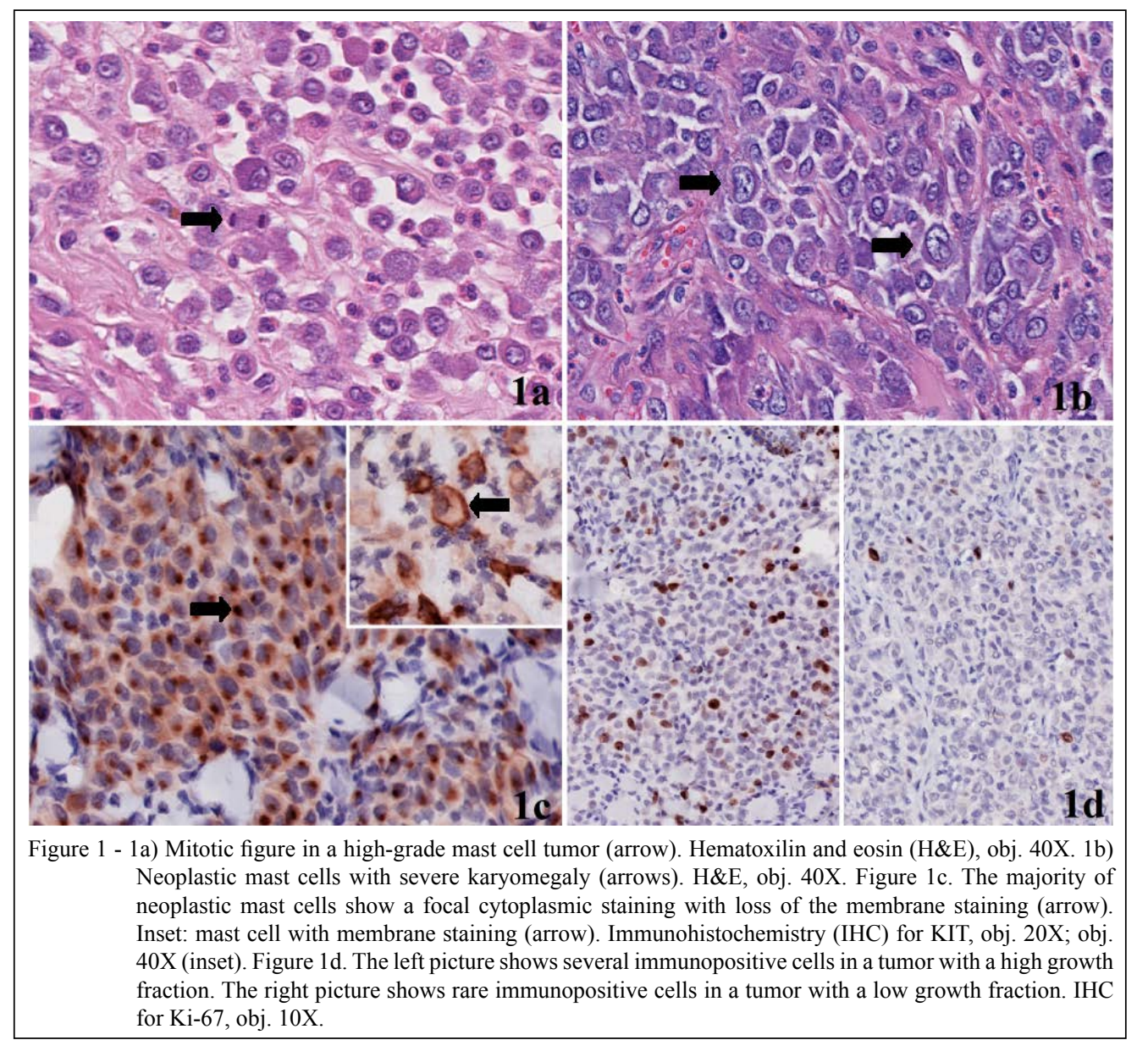

2015; SABATTINI et al., 2015), although it is not consistently applied in the diagnostic routine of many Brazilian laboratories. This system includes more objective criteria and has been associated with a significant prognostic value, mainly when compared to the grading system proposed by PATNAIK et al. (1984) (PS) (VASCELLARI et al., 2012; TAKEUCHI et al., 2013; SABATTINI et al., 2015). Therefore, many North American laboratories have been using the KS in their diagnostic routine, frequently together with the PS. The KS was essential for the identification of potentially aggressive tumors in this study: $30.8 \%$ of the mast cell tumors were considered high-grade based on this new grading system and these highgrade tumors had a moderate correlation with a high growth fraction, another prognostic indicator.

Despite being considered the main tool in the evaluation of CCMTs for at least 40 years (BOSTOK et al., 1973; PATNAIK et al., 1984; KIUPEL et al., 2011), the sole use of histopathology has been proven to be ineffective for the prognostication of CCMTs (KIUPEL et al., 2004; KIUPEL et al., 2011). This has motivated the use of auxiliary techniques on the MCCTs evaluation. The canine mast cells contain a membrane tyrosine kinase receptor (KIT) encoded by a gene called $c$-kit (YARDEN et al., 1987). In 1999, a research group described a series of mutations termed ITD affecting the juxta membrane domain (mainly exon 11) of this gene in CCMTs (LONDON et al., 1999) and enrolled in the development and progression of these tumors. It is determined that $15-40 \%$ of CCMTs are positive for ITD, and that their presence is related to an aggressive biological behavior (DOWNING et al., 2002; ZEMKE et al., 2002; WEBSTER et al., 2006) and to an increased responsiveness to therapy with the so-called "tyrosine kinase inhibitors" (PRYER et al., 2003). Due to the relatively high prevalence, strong prognostic value and great influence on therapeutic approach associated with the presence of ITD in CCMTs, the investigation of these mutations by means of PCR has become a routine protocol in the CCMT evaluation particularly at North America. In Brazil; however, the PCR for exon 11 is still rarely used. In this study, 


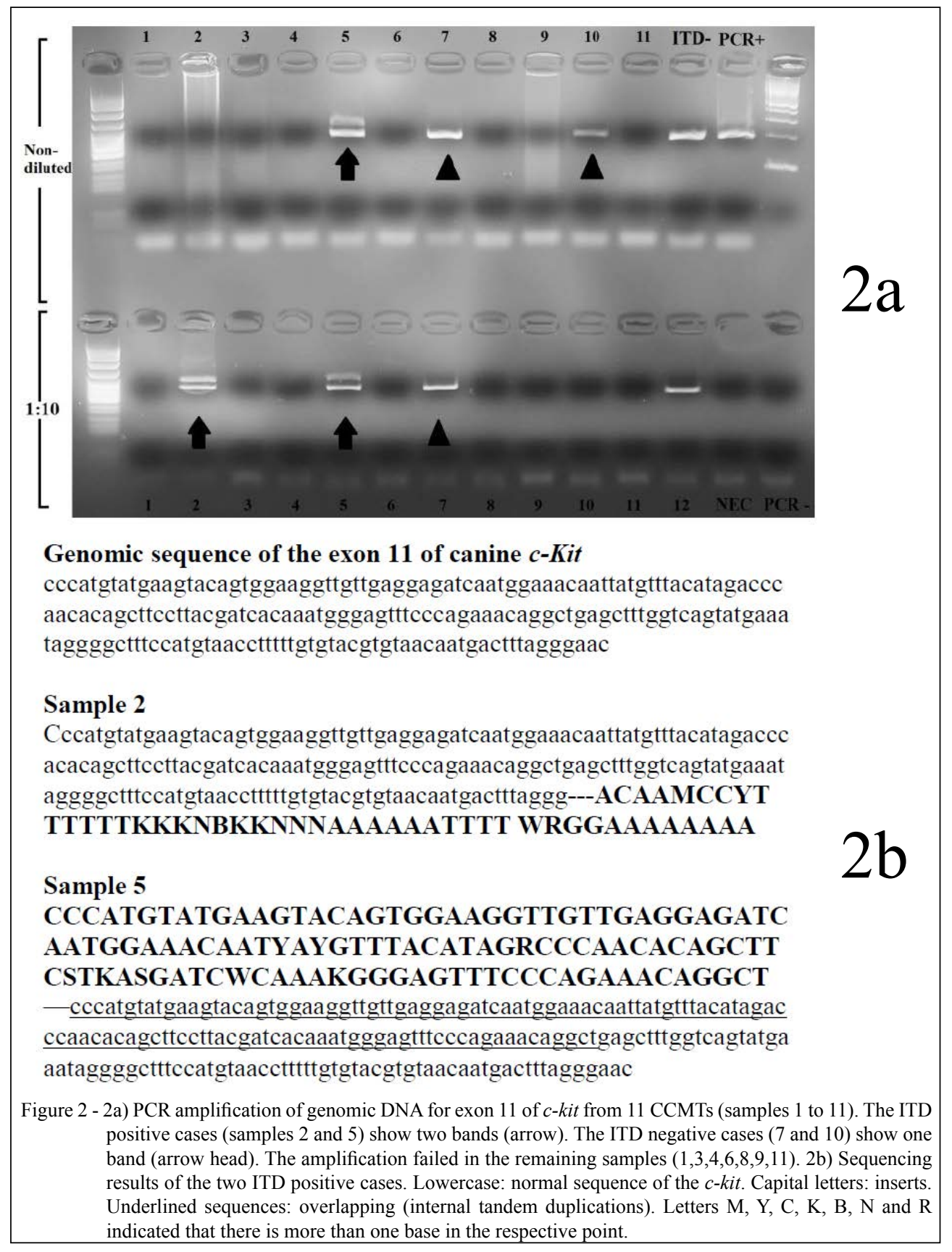

only two tumors were positive for ITD. The limitation on the number of samples submitted to PCR (due to low budget), the failure in the PCR amplification of five samples and the low number of positive cases for mutations prevented the authors from this study to determine a reliable prevalence for ITD. It also prevented to correlate the presence of these mutations with the other prognostic indicators tested here.

KIUPEL et al. (2004) have recently correlated the loss of membrane expression and concurrent gain of cytoplasmic labeling of KIT to a shorter survival time and higher risk of recurrence. Ever since, this supplementary technique has been incorporated as a new variable in the assessment of the biological behavior of CCMTs. WEBSTER et al. (2006) showed a positive correlation between the increased cytoplasmic expression of KIT and the presence of ITD $c$-kit mutations, suggesting that these mutations may play a role in the aberrant cytoplasmic KIT location in some of these tumors.

Ciência Rural, v.46, n.10, out, 2016. 
All CCMTs included in this study showed a KIT expression pattern II, which suggested a worse prognosis (KIUPEL et al., 2004). These results were already expected, since this study included only intermediate tumors (grade II).

The use of Ki-67, a nuclear protein expressed in cycling cells (YARDEN et al., 1987), as a cellular proliferation marker in CCMTs is well established in the literature (SCASE et al., 2006; WEBSTER et al., 2007; VASCELLARI et al., 2012). The number of Ki-67-positive cells appears to be an important prognostic indicator in different studies (SCASE et al., 2006; WEBSTER et al., 2007; VASCELLARI et al., 2012), but the cut-off point to determine which tumors are likely more benign and which are likely more aggressive is extremely variable from one article to another. WEBSTER et al. (2007) identified a statistically significant cutoff value of 23 when comparing the growth rate to several prognostic indicators. This article is referred by one of the most famous veterinary pathology textbooks (MAXIE, 2015), and its cut-off value has been chosen to be used in this study.

The failure of the IHC in two samples represented a minor limitation of this study, and is probably related to the long formalin-fixation period, a common issue in Brazilian laboratories. The major limitation of this study was the failure of the DNA amplification in seven samples submitted to PCR. There are several pitfalls that prevented or hindered the DNA extraction from formalin fixed and paraffin embedded (FFPE) tissues (MAES et al., 2014). The identification of sample-processing issues and use of good laboratory practices may help overcoming these obstacles. This includes adequate sample cleavage $(0.5$ to $1 \mathrm{~cm}$ thick), quality and quantity control of the formaldehyde, short fixation time, and quality and temperature control of the paraffin (MAES et al., 2014).

\section{CONCLUSION}

The histologic and immunohistochemical techniques used in this study were easily applicable and when used together, improved the identification of potentially aggressive tumors. Failure on the DNA amplification of several samples was the major limitation of this study. Enforcing good laboratory practices in Brazilian laboratories might help overcome this kind of issue. This study was important to identify limitations and to confirm the applicability of these different techniques on a routine diagnostic basis in Brazil; thus, encouraging the use of these methods on the prognostication of CCMTs from this country.

\section{ACKNOWLEDGEMENTS}

This research was supported by the Conselho Nacional de Desenvolvimento Científico e Tecnológico (CNPq) - Brazil. We thank Ms. Del Philips and Dr. Alejandra Baudena for their technical help. Mariana M. Flores owns a scholarship from Coordenação de Aperfeiçoamento de Pessoal de Nível Superior (CAPES).

\section{SOURCES AND MANUFACTURES}

'Dako, Carpinteria, California, United States.

IAnatech, Battle Creek, Michigan, United States.

III Qiagen, Valencia, California, United States.

\section{REFERENCES}

BOSTOK, D.E. The prognosis following surgical removal of mastocytomas in dogs. Journal of Small Animal Practice, v.14, p.27-41, 1973. Available from: <http://onlinelibrary.wiley.com/ doi/10.1111/j.1748-5827.1973.tb06891.x/abstract $>$. Accessed: Dec. 03, 2015. doi: 10.1111/j.1748-5827.1973.tb06891.x.

DOWNING, S. et al. Prevalence and importance of internal tandem duplications in exons 11 and 12 of c-kit in mast cell tumors of dogs. American Journal of Veterinary Research, v.63, p.17181723, 2002. Available from: <http://avmajournals.avma.org/doi/ abs/10.2460/ajvr .2002.63.1718>. Accessed: Nov. 27, 2015. doi: 10.2460/ajvr.2002.63.1718.

GOLDSCHMIDT, M.H.; HENDRICK, M.J. Tumors of the skin and soft tissues. In: MEUTEN, D.J. Tumors in domestic animals. 4.ed. Ames: Iowa State, 2002. Cap.2, p.44-117.

GROSS, T.L. et al. Mesenchimal neoplasms and other tumors. In: _. Skin diseases of the dog and cat. Clinical and histopathologic diagnosis. 2.ed. Oxford: Blackwell Science, 2005. p.709-772.

JONES, C.L.R. et al. Detection of c-kit mutations in canine mast cell tumors using fluorescent polyacrylamide gel electrophoresis. Journal of Veterinary Diagnostic Investigation, v.16, p.95-100, 2004. Available from: <http://vdi.sagepub.com/ content/16/2/95.full.pdf + html $>$. Accessed: Jun. 09, 2015. doi: $10.1177 / 104063870401600201$.

KIUPEL, M. et al. Proposal of a 2-tier histologic grading system for canine cutaneous mast cell tumors to more accurately predict biological behavior. Veterinary Pathology, v.48, p.147-155, 2011. Available from: <http://vet.sagepub.com/content/48/1/147.short>. Accessed: Jun. 09, 2015. doi: 10.1177/0300985810386469.

KIUPEL, M. et al. The use of KIT and tryptase expression patterns as prognostic tools for canine cutaneous mast cell tumors. Veterinary Pathology, v.41, p.371-377, 2004. Available from: $<$ http://vet.sagepub.com/content/41/4/371.short $>$. Accessed: June 09, 2015. doi: 10.1177/0300985810386469.

LONDON, C.A. et al. Spontaneous canine mast cell tumors express tandem duplications in the proto-oncogene $c$-kit. Experimental Hematology, v.27, p.689-697, 1999. Available from: <http://www. 
sciencedirect.com/science/article/pii/S0301472X98000757>. Accessed: Jun. 09, 2015. doi: 10.1016/S0301-472X(98)00075-7.

MAXIE, M.G. Jubb, Kennedy, and Palmer's pathology of domestic animals. 6.ed. St Louis: Elsevier Saunders, 2015. V.3, p.57-59.

MAES, I.K. et al. Beyond H\&E: integration of nucleic acidbased analyses into diagnostic pathology. Veterinary Pathology, v.5, p.238-256, 2014. Available from: <http://vet.sagepub. com/content $/ 51 / 1 / 238$.short $>$. Accessed: Dec. 20, 2015. doi: $10.1177 / 0300985813505878$.

MAULDIN, E.A.; PETERS-KENNEDY, J. Integumentary system. In: MAXIE, M.G. Jubb, Kennedy, and Palmer's pathology of domestic animals. 6.ed. St Louis: Elsevier Saunders, 2015. V.3, p.57-59.

PATNAIK, A.K. et al. Canine cutaneous mast cell tumor: morphologic grading and survival time in 83 dogs. Veterinary Pathology, v.21, p.469-474, 1984. Available from: <http://vet. sagepub.com/content/21/5/469.full.pdf+html>. Accessed: Jan. 02, 2015. doi: $10.1177 / 030098588402100503$.

PRYER, N.K. et al. Proof of target for SU11654: Inhibition of KIT phosphorylation in canine mast cell tumor. Clinical Cancer Research, v.9, p.5729-5734, 2003. Available from: $<$ http://clincancerres.aacrjournals.org/content/9/15/5729.short $>$. Accessed: Dec. 02, 2015. doi: 10.1007/s00432-014-1664-9.

SABATTINI, S. et al. Histologic grading of canine mast cell tumor: is 2 better than 3? Veterinary Pathology, v.52, p.70-73, 2015. Available from: <http://vet.sagepub.com/content/52/1/70.short>. Accessed: Dec. 05, 2015. doi: 10.1177/0300985814521638.

SCASE, T.J. Canine mast cell tumors: correlation of apoptosis and proliferation markers with prognosis. Journal of Veterinary Internal Medicine, v.20, p.151-158. Available from: <http:// onlinelibrary.wiley.com/doi/10.1111/j.1939-1676.2006. tb02835.x/pdf>. Accessed: Jan. 07, 2016. doi: 10.1892/0891-6640(2006)20[151:CMCTCO]2.0.CO;2.

TAKEUCHI, Y. et al. Validation of the prognostic value of histopathological grading or c-kit mutation in canine cutaneous mast cell tumours: a retrospective cohort study. Veterinary Journal, v.196, p.492-498, 2013. Available from: $<$ http://www. sciencedirect.com/science/article/pii/S1090023312005229>. Accessed: Jun. 08, 2015. doi: 10.1016/j.tvj1.2012.11.018.

VASCELLARI, M. et al. Expression of cKi67, BCL-2, and COX-2 in canine cutaneous mast cell tumors: association with grading and prognosis. Veterinary Pathology, v.50, p.110-121, 2012. Available from: <http://vet.sagepub.com/content/50/1/110.full.pdf + html $>$. Accessed: Dec. 02, 2015. doi: 10.1177/0300985812447829.

WEBSTER, J.D. The role of $c$-KIT in tumorigenesis: evaluation in canine cutaneous mast cell tumors. Neoplasia, v.8, p.104111, 2006. Available from: <http://www.sciencedirect.com/ science/article/pii/S1476558606800199>. Accessed: Dec. 02, 2015. doi: 10.1593/neo.05622.

WEBSTER, J.D. et al. Cellular proliferation in canine cutaneous mast cell tumors: associations with $c$-Kit and its role in prognostication. Veterinary Pathology, v.44, p.298-308, 2007. Available from: <http:/vet.sagepub.com/content/44/3/298.short>. Accessed: Jun. 09, 2015. doi:10.1354/vp.44-3-298.

YARDEN, Y. et al. Human proto-oncogene c-kit: a new cell surface receptor tyrosine kinase for an unidentified ligand. EMBO Journal, v.6, p.3341-3351, 1987. Available from: $<$ http://www.ncbi.nlm.nih.gov/pmc/articles/PMC553789/pdf/ emboj00251-0138.pdf>. Accessed: Jan. 06, 2016.

ZEMKE, D. et al. Mutations in the juxtamembrane domain of c-KIT are associated with higher grade mast cell tumors in dogs. Veterinary Pathology, v.39, p.529-535, 2002. Available from: $<$ http://vet.sagepub.com/content/39/5/529.short $>$. Accessed: Jun. 09, 2015. doi: 10.1354/vp.39-5-529. 